Treatment of Herpes Simplex with Co-trimoxazole

SIR,-Since my letter on this subject (17 August, p. 473) I have had several inquiries about the details of treatment.

I give two tablets (or the equivalent in suspension) of co-trimoxazole twice daily to adults and proportionate doses to children. Treatment should be started as early as possible, preferably in the stage of prickly, itchy swelling before the vesicles have fully formed, though healing is expedited even if treatment is delayed until there is florid vesiculation. Early treatment usually causes the lesions to abort or resolve within two to three days, but I continue treatment for a week as I have found that this considerably reduces the incidence of recurrences. For herpes zoster I give the same daily dosage but for 10 to 14 days. I would reiterate that concurrent treatment with a penicillin nullifies the effect.

Apart from interference by penicillins, which is so far unexplained, $15-20 \%$ of patients do not respond to the treatment. This seems to be an individual peculiarity as the same patients have not benefited on repeated trial in a series of recurrent lesions. The reason for this failure to respond is not clear, but I suspect that these people may have an anomaly of thymidine metabolism. Klemperer et al. ${ }^{1}$ reported the presence of a virus-specific thymidine kinase in herpes-infected cells, and Gaylarde and Sarkany $^{2}$ found that only about $80 \%$ of activated human lymphocytes showed inhibition of uptake of radioactive-labelled thymidine under the influence of cotrimoxazole. Obviously this is a speculation which needs elucidation, but the similarity between the proportions of reactors and nonreactors is very suggestive.

Even with these reservations cotrimoxazole offers hope of a simple, relatively safe, and inexpensive treatment for these distressing and, in some cases, potentially dangerous infections, and also of long-term control by reducing the pool of carriers. Amantadine $100 \mathrm{mg}$ twice daily is worth trying in patients who do not respond to co-trimoxazole. It seems to accelerate healing, though less dramatically, but not to prevent recurrences.-I am, etc.,

Craig Phadrig Hospital

Paula H. Gosling

Inverness

1 Klemperer, H. G., et al., Virology, 1967, 31, 120 fournal, 1972, 3, 144.

\section{Screening for Sickle-cell Disease}

SIR,-Dr. F. F. Casale (19 October, p. 163) asks, "Should the absence of a sickle-cell test in fit and non-anaemic adults and older children of possible Negro descent be a contraindication to general anaesthesia?" The answer is "yes," because patients with sickle-cell disease may neither be anaemic nor have much in the way of previous illness, particularly if they are resident in Western countries.

If patients with a high concentration of haemoglobin S (and this may include some patients with sickle-cell trait ${ }^{1}$ ) are to be anaesthetized without precipitating a crisis there must be adequate oxygenation and ventilation, cardiac output and circulating blood volume must be maintained, and acidosis must be avoided. ${ }^{2}$ However, as has been pointed out, ${ }^{3}$ it is impossible for an anaesthetist to guarantee full oxygenation all the time and, I would have thought, least of all in the dental chair.

One of the principles of safe anaesthesia is that the anaesthetist should have as much relevant information as possible about a patient before he commences the anaesthetic.

\section{Consultant Contract}

SiR,-Mrs. Castle's offer of better terms to whole-time consultants is, indeed, likely to drive a wedge between them and their parttime colleagues at a time when unity is more than ever desirable; and we see a danger that some part-time consultants may assist her all too well when they refer to extra payment for those whose specialty or commitments permit no material private practice as a "bribe" and sometimes add further uncomplimentary remarks.

Worse, there is a danger that our negotiators may appear to be taking sides in this potential argument, because their praiseworthy efforts to improve the offer made to part-time consultants could all too easily seem like criticizing the offer to wholetime consultants as unduly generous, which we feel sure it is not. We learn with some dismay that our negotiators appear to have turned down an offer of an increased $18 \%$ for those of us who will never do any private practice.

Whole-time consultants have laboured under a series of disadvantages, including unfavourable tax schedules, during the first quarter-century of the Health Service, and we see no reason why they should refuse some form of compensation for this. While we want to see a fair part-time contract for our colleagues, and particularly for those who have been manoeuvred into the socalled maximum part-time contract, we feel less than enthusiastic in supporting a change which might be to our detriment and no one's benefit.

We cannot agree with the reasoning which says that whole-timers can undertake further remunerated N.H.S. activities. Whence comes the time? To those whole-timers who are older, their scanty leisure is valuable. Some may feel able airily to refuse an extra $18 \%$, which is little in practice after deducting schedule $\mathrm{E}$ tax; a loss of $18 \%$ of their widow's pension is another matter. We feel it is unfair to suggest that doctors with material private practice additional to N.H.S. pay should receive almost the same salary (10/11ths) as whole-timers and think this is unacceptable.

We want our part-time colleagues to achieve a better contract. We want to support them in this, but we would like to feel certain that our negotiators are seeking more for the part-time consultants, not less for the whole-time consultants. There are limits to our altruism; we appeal not to be pushed beyond them.-We are, etc.,

W. FINE

G. Dalawell Walker C. V. SHANAHAN JOHN N. RIMMER

Newsham General Hospital Liverpool
SIR,-At a representative meeting of pathologists in the North East Thames Regional Hospital Authority the following resolutions were agreed, 25 people being in favour, with three abstaining, in a total attendance of 28.

(1) The Department of Health and Social Security proposals for a new consultant contract were regarded as forming a basis for negotiation since they do provide for a complete commitment allowance.

(2) The proposals for the adoption of a consultant contract based on an item-ofservice basis were not supported.

(3) The meeting did not support the contract as proposed by the Central Committee for Hospital Medical Services.-I am, etc.,

Basildon, Essex

\section{J. P. WHITEHEAD} Chairman

SIR,-It is regrettable that the negotiations between the Health Departments and the B.M.A. on the consultants' contract have not reached a satisfactory conclusion and that the senior hospital staff have been forced to work strictly to their contracts as from 2 January.

I feel strongly that the medical profession should present a united front at this stage and that other branches of the profession should apply sanctions from this date in support of the consultants. - I am, etc.,

Bideford, Devon

ALAN J. RILEY

\section{Doctors' Pay}

SIR,-I was flabbergasted by some solicitor friends of mine who informed me that they are valued at, and paid at the rate of, £8-12 per hour when working for the State.

I would be most grateful if someone could tell me why we in the medical profession come off so much worse, or do we just have to accept the fact that we are an inferior profession?-I am, etc.,

Hailsham, Sussex

RODNEY JOHNSON

SIR,-It is a sad reflection upon the deplorable level of senior hospital doctors' pay that the B.M.F. of 14 December (p. xi) should bear an advertisement for a post of medical officer to British Leyland in which the minimum salary would be not less than $£ 6,500$ plus other benefits. This level of salary is equivalent to that of a whole-time consultant with four increments.

That this post, for which no previous industrial experience is needed, should be 